\title{
Public and Private Investment and Economic Development in Iraq (1970-2010)
}

\author{
Jwan Hussein and James Benhin
}

\begin{abstract}
Based on the neoclassical growth model of Solow (1956), this study analyses the macroeconomic determinants of economic growth, examining the effect of public and private investment on economic growth in Iraq from 1970 to 2010.Cointegration and error correction models were applied to the time series data, followed by a Johansen cointegration test of trace and maximum eigenvalue statistics to establish long run equilibrium relationships among the variables in the model. This study also estimated an error correction model (ECM) and the significance of the coefficient on the error correction term confirms the long run relationship between the explanatory variables and economic development. The empirical results suggest that, in the long run, private investment, public investment, growth in the labour force and growth in oil revenues effect real gross domestic product (GDP) positively and statistically significantly; however, price and exchange rate volatility are found to have an adverse impact on real GDP. In light of these results, several policy recommendations are made to conclude.
\end{abstract}

Index Terms-Economic development, Iraq, private and public investment, cointegration.

\section{INTRODUCTION}

Investment is a crucial for economic development, as it increases productivity, the employment and technological progress. In the last few decades, one of the important issues in macroeconomic and development economics was the impact of public and private investment on economic growth and has been the subject of renewed consideration in the academic literature. There is a general consensus that these two elements of investment have a differencing impact on economic growth and social conditions. Since the distinction between public and private investment matters for economic growth, it is essential to understand the linkages between these two components.

Generally, academic research suggests that public investment in human capital and infrastructure services, such as transportation, communication, and sanitation, is complementary to private investment, through increasing its productivity, and thus having a significant positive impact on the economic growth [1]-[6]. However, some empirical literature [7]-[9] suggests that public investment may also 'crowd out' private investment through over utilising scarce resources and reducing the aggregate amount of savings available for private investment; here, public investment is said to have an adverse effect on economic growth. In most

Manuscript received May 10, 2014; revised July 10, 2014

The authors are with the Plymouth University School of Business and Management, UK(e-mail: jwan.hussein@postgrad.plymouth.ac.uk, james.benhin@plymouth.ac.uk). developing economies, policymakers concerned with growth suggests that it is not only the aggregate level of the investment that matters for economic growth, but how to split between its public and private investments.

This study contributes to the empirical literature on economic growth by analysing the determinants of economic growth in Iraq from $1970-2010$. The analysis in this paper is based on the neoclassical framework also adopted by [10]-[12], who attempt to empirically investigate how public and private investment affect economic growth. This is an important and unsettled policy issue, which warrants further this empirical work. Additionally, this study develops a simple analytical model which includes other theoretical determinants of growth, such as human capital and macroeconomic instability. Furthermore, it also assesses the differencing impacts of public and private investment on economic growth.

The rest of this paper is organised as follows: section two provides a discussion of economic growth, public and private investment in Iraq; section three presents a review of the relevant empirical literature; and section four discusses the methodology, theoretical framework and model specification; the results of the empirical analysis and their implications are presented in the section five; section six concludes and suggests some policy recommendations.

\section{Public AND Private InVESTMENT Performance IN IRAQ}

Before oil exploration Iraq's economy was based almost exclusively upon agriculture. However, after 1970 economic performance was relatively impressive, and nationalization of the oil industry in 1972 provided Iraq with a source of sustainable financial strength, leading the Iraqi government to adopt an expansionary fiscal policy that stimulated economic activity, motivate production cycle, and encourage consumption. Since then, the economy has experienced considerable structural change and the prospects for economic development have changed with it.

Historically, the Iraqi economy experienced a high average of annual growth of approximately $8.3 \%$ between 1970 and1980, while the ratio of public and private investment to GDP were around $12.4 \%$ and $3.5 \%$ respectively. With regard to the Iraqi's economy, Foot argued that Iraqi oil resources in the 1970s allowed the country to reach the middle- income status, with a modern infrastructure, and good education and healthcare systems. By the beginning of the1980s, Iraq had the second largest economy in the Arab world, after Saudi Arabia, and the third largest economy in the Middle East. Having adopted a centrally planned economy dominated by the state [13] 
Furthermore, increasing world oil prices reflected positively on crude oil revenue, encouraging the state to adopt extensive investment programs outside of the oil sector; consequently, both the oil and non-oil sectors grew rapidly. At the time, these economic reforms were noticeably reflected in the Iraqi people's standard of living, who enjoyed increasing economic and social prosperity. Generally, the Iraqi economy of the 1970s appears to be somewhat of a success story when evaluated using a range of recognized economic and social development measures. However, between 1980 and 2003 Iraq failed to maintain its economic success of the 1970's, being confronted by military conflict, in the form of the first Gulf War in 1980-1988, the second Gulf War in 1991, a range of internationally enforced economic sanctions from 1991-2003, and the collapse of a governing regime established since 1968.

The economic situation began to deteriorate from 1980 with the outbreak of the first Gulf War, as hostilities devastated the county's economic base and brought oil production to a halt. Oil revenue as a share of the GDP decreased from $71 \%$ in 1980 to $17 \%$ in 1986 , as most of Iraq's Gulf port facilities were destroyed, and the economy averaged a negative growth rate of approximately $-0.5 \%$ between 1980 and 1989.

Development indicators generally reflected this destabilization in economic, political, social, and security conditions. Real per capita income experienced a considerable decline from $1097 \$$ in 1973 to $594 \$$ in 1995 , possibly as a result of increasing amounts of public expenditure covering military costs. The priority of economic policies during periods of conflict was to support war efforts and resist sanctions, rather than investment in capital formation and infrastructure, reversing the positive trends of the 1970s.

The devastation to Iraq's economy caused by this military conflict resulted in private investment as a share of GDP to decline over time. Private investment (private fixed capital formation) as a share of GDP declined considerably from $7.1 \%$ in 1981 to around $1.7 \%$ in 2003 . While, public investment decreased to $13.5 \%$ in 2003 from $33.2 \%$ in 1989. Although, public and private investment have fallen together over the periods 1980-2003, the private investment experienced a higher decline than public investment. This can be attributed to public investment in infrastructure declined because a greater proportion of public expenditure allocated to military spending. Moreover, private investment might be declined due to the impact of sanctions deterring investment, the uncertainty that accompanies military conflict in the private sector, and even the collapse of institutions that are important to encourage investment. The decline in the importing of capital assets and the failure to implement economic development plans during this period of destabilisation, were further obstacles faced by private investors, a main consequence of which was to paralyze many domestic sectors, negatively affecting their productive capacity.

However, the economic performance during the post-war period has been relatively impressive, as the average annual growth rate of the economy has been reported to be approximately $12.6 \%$ between 2003 and 2010. The Iraqi government has introduced and implemented several national economic development plans in order to revive and sustain economic growth, decrease the rate of unemployment, reduce income inequality, and reduce poverty. Liberating interest exchange rates, as well as reducing restrictions on the flow of capital, were also considered to strengthen the financial systems' technical and guidance roles in the provision of supporting financial advice to private sector investors.

Furthermore, economic and political stability were a priority for the Iraqi government, as it was highly important to achieve economic growth and they sought to give the private sector a leading role in job creation and the nation's economic development. Furthermore, the Iraqi government intimated that public investment should be directed towards providing basic and necessary infrastructure services, that would play a supplementary role to private investment.

To meet this end, Iraq's government has adopted the midterm national development plan and proposed five years plan to cover the period of 2010-2014 as well, to implement policies that diversifies the economic base of the country, which currently mainly depended on the oil and agricultural sectors. For the first time, the new economic philosophy has been proposed that is based on a free market ideology, with an emphasis on increasing both domestic and foreign investment rates in the country.

Post 2003 was marked the beginning of increasing government involvement in the economy. Subsequently, the average public fixed capital formation to GDP ratio increased to an average of $14.20 \%$ between 2003-2010, up from an average of $10.58 \%$ seen between 1980-2003. However, a more prominent decrease was observed in the private investment to GDP ratio, not exceeding 3\% even during the best circumstances during the same period, a ratio that is considered to be too low. However, despite economic reform should include all economic sectors in the country, an increase in the rate of private and public investment relative to GDP has not particularly materialized yet as proposed.

Iraq's economy continues to be confronted by many problems, such as instability in the absence of the security, a high rate of inflation, low employment, and depreciation of the local currency, bringing more obstacles and uncertainty to the investment climate. Put succinctly, the Iraqi government has been failed to achieve its required macroeconomic objectives.

From a long term perspective and in the light of the above, the average ratio of public investment to GDP was approximately $14.6 \%$ during 1970-2010. In comparison, the ratio of private investment to GDP was $2.5 \%$ over the same period, showing that public investment was much higher than private investment figure. 1 . This can be attributed to the several reasons such as a large proportion of the lacking private investment over this period might stem from the instability caused by conflict, as well as an economic sanction imposed internationally that would have forbid FDI. Both of these would likely deter private investment, both internally and internationally, as it makes Iraq a very unattractive proposition for a return on investment. On the another view, this may because private investments are crowded out by public sectors, resulted that private sectors not involving in large projects and were limited to the individual work, small facilities in the terms of the organization, production and investment. The private sector did not, therefore, play a prominent role in encouraging 
economic growth. For 40 years, the private sector has been subjected to violent systemic shocks, policy fluctuations, and laws that promoted ownership fragmentation, keeping the private sector away from some economic activities. In addition, the private sector effectively became a contractor for the public sector, as its activities became linked to those of the public sector with its role in the economy increasingly marginalised.

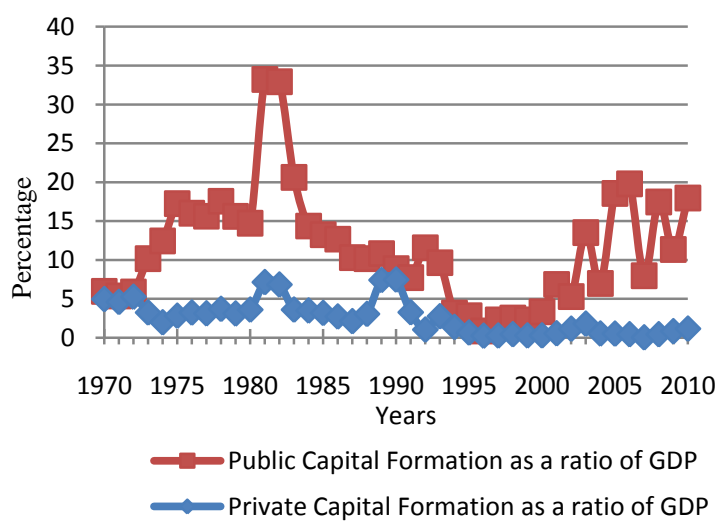

Fig. 1. Annual private and public investment as $\%$ of the GDP.

\section{LITERATURE REVIEW}

The traditional neoclassical growth model based on the aggregate production function, originally developed by Solow (1956) and Ramsey (1982), is still the most widely used method for establishing factors influencing economic growth, and assume that the process of capital accumulation is a key determinant of economic growth. In the other words, physical capital accumulation, driven by higher investment shares in GDP, is generally related with higher per capita income growth rates.

Recently, this model has been supplemented by endogenous growth models that include knowledge and human capital as a source of increasing returns in a different form of the aggregate production function. For example, The essencial study by Romer who established through the empirical analysis of over 100 countries that for a given initial level of real per capita GDP, growth in real per capita GDP is related to an increased level of schooling (human capital), low inflation (price stability) and improvements in trade (free trade externalities) [14]; similar assumptions are established by Barro[15] A main finding of the World Bank (1993) recognized that, in East Asia, economic growth was mostly explained through increases of human capital.

The key feature of endogenous growth models is the role played by human capital accumulation as, according to [16]-[18] human capital positively affects the productivity of all other factors of production and may also generate innovative opportunities or products that support technological progress. Endogenous growth models suggest that sustained growth is achieved through assuming the endogeneity of technological progress. This differs from the Solow (1956) growth model which assumes the level of technology to be exogenously determined, instead emphasising the role of physical capital accumulation and progressive economic policy to achieve sustained economic growth.
Following these theoretical arguments, a considerable amount of research has been devoted in developing economies to investigate the prospective impact of increased public capital formation on private investment. There is a broadly held belief that public investment many not only encourage economic growth directly, but also indirectly via promoting private investment. Therefore, the nature of the relationship between these two forms of capital is still the subject of much controversy [6], [19], [20]. Accordingly, the relative influence of public and private investment has been the subject matter of much research, largely confirming that they perform a different function and influence productivity differently [6], [9], [21].

For example, it has been widely discussed by the empirical literature that expansionary fiscal policies financed through fiscal deficits result in a reduction in private investment by pushing up interest rates, reducing the availability of private funds for financing investment, or both (interest rate/credit effect). However, a more careful examination proposes that this conclusion may not be conclusive, as such expansionary fiscal policies may lead to increases in public infrastructure that can be complementary to private investment being beneficial for economic growth through its positive influence on the productivity of private investment [22], [23].

Undoubtedly, in many developing countries the insufficiency of infrastructure is a substantial obstacle to private capital formation. There are clear economies of scale from the provision of public goods and services, such as power plants, roads, communication utilities, irrigation, social services, etc., from which private sector can achieve significant benefits [21], [24], [25]. This is most likely to be true in those developing countries where the existing stock of infrastructure capital is inadequate [26]. However, in countries that have large levels and a high quality of public infrastructure, the argument that public investment is complementary to private investment is less likely to hold. In this context, there could be greater advantages to the private sector if public expenditure looks improves the efficiency of infrastructure, as opposed to increasing its quantity [19], [27].

Public investment in infrastructure might also signify a long run adherence of the government to its policy program of restructuring the economy, and thus appease a lack of credibility and perceived uncertainty, creating a more favourable environment for private investment projects [1], [28], [29]. Additionally, a large part of public capital formation in developing countries is undertaken by state owned enterprises and the output of public enterprises, in the form of capital goods industries, constitutes an essential input for investment in the private sector. In this case, expanding the capacity of public enterprises could also lead to an increase in private investment undertaken for the purpose of satisfying additional demand.

However, the overall net effect is theoretically less established and changes across countries in terms of both sign and magnitude. On the one hand, it is argued non-infrastructure investment tends to exert a negative influence on the private capital formation. It is also argued, in a case of provision of goods by public enterprises, that these relevant sectors are more competitive rather than complementary (for example in the manufacturing, mining and tourism sectors) as these activities require substantial 
funds, making private investors reluctant to invest in these sectors and compete [5], [24].

In recent years, analysing the interaction between public investment, private investment and economic growth has been the focus of even greater consideration and the effects of public investment on private investment has shown mixed results. Some research demonstrates the "crowding out" effect in some countries, whereas others research show a "crowding in" in other countries. Even when considering the same country, various studies show conflicting results, but this is possibly because of the utilisation of different methodological approaches that may also have analysed different time periods.

Furthermore, The empirical study by Naqvi who examined the relationship between public and private investment and economic growth in Pakistan, by adopting a cointegrated VAR based approach, over the period 1964-2000 [30]. The annual change in the real exchange rate was used as a proxy for uncertainty that was also utilised in the short-run VECMs under the hypothesis that investment decisions are likely to be affected by recent uncertainty. A model based on the 'accelerator model hypothesis' suggested that economic growth encourages both public and private investment; however, investment by itself has no significant influence on economic growth. The empirical results suggested that past public investment tends to have a positive impact on future private investment. Whereas uncertainty is shown to have a greater negative impact on private investment than public investment.

According to Khan and Ghura who made a revision to the Solow growth model, suggesting the possibility of differential effects from private and public investment on economic growth over time and across countries [10], [26]. They concluded in their studies that private capital formation has a higher marginal productivity and encourages economic growth to a greater extent than public investment. Finally, they also report that other additional explanatory factors, such as human capital and macroeconomic stability, were seen to also significantly influence economic growth within their model.

In the last few decades, many studies have begun to focus on the efficiency of the public sector and on the role of good governance in determining the productivity of public investment. A strong positive evidence has found by Aschauer who suggesting that role for non-military public capital stock in determining the rate of return to private capital, consistent with the assumption that public and private capital stocks are complementary inputs to private production technology [1]. Similarly, Keefer argued that public investment is considerably higher in some countries with bad institutions, which they suggest is a clear reflection of the enhanced rent-seeking actions of governments in environments where property rights are less secure [31]. Furthermore, Mauro investigates whether predatory behaviour by corrupt politicians distorts the composition of government expenditure; their results suggest that education spending is harmfully affected by corruption [32]. In countries with weak institutions that are more susceptible to corruption, the composition of public expenditure would be biased towards investment in capital, rather than expenditure on social welfare services, education and health.

\section{THEORETICAL FRAMEWORK AND MODEL SPECIFICATION}

This study adopts the basic neoclassical growth framework of Solow (1956) a framework that has been used broadly in previous research on the influence of public and private investment on long run economic growth in developing countries[10], [21], [33]-[36]. Hence, many studies have attempted to develop or extend the original version of the model through including some other factors as explanatory variables, such as human capital and macroeconomic stability.

Initially, the model starts with a Cobb-Douglas production function framework relating output to factor inputs and other variables that represent factor productivity:

$$
Y=A F(K, L, Z)
$$

where $Y$ is the level of output, $K$ is the stock of the physical capital, $L$ represents the labour force and $Z$ denotes a vector which of other variables assumed to influence economic growth. $A$ denotes a measure of productivity that is assumed to be exogenous.

The expected signs of all partial derivatives of $Y$ are expected to be positive. Equation (1) can be expressed as a growth model as follows:

$$
\begin{aligned}
& \frac{d Y}{Y}= \\
& {\left[\frac{d A}{A}\right]+\left[A \cdot \frac{\partial Y}{\partial k}\right] \frac{d k}{Y_{t-1}}+\left[A \cdot \frac{\partial Y}{\partial L} \cdot \frac{L}{Y}\right] \frac{d L}{L_{t-1}}+\left[A \cdot \frac{\partial Y}{\partial Z} \cdot \frac{Z}{Y}\right] \frac{d Z}{Z_{t-1}}}
\end{aligned}
$$

Equation (2) can be simplified for estimation purposes, leading to equation (3);

$$
\frac{\Delta Y}{Y}=\beta_{0}+\beta_{1} \frac{\Delta I}{Y_{t-1}}+\beta_{2} \frac{\Delta L}{L_{t-1}}+\beta_{3} \frac{\Delta Z}{Z_{t-1}}
$$

where

$\beta_{0}=\frac{d A}{A}$, represents the constant term assumed to capture the growth of the productivity

$\beta_{1}=A \cdot \frac{\partial Y}{\partial k}$, represents the marginal productivity of capital

$\beta_{2}=A \cdot \frac{\partial Y}{\partial L} \cdot \frac{L}{Y}$, represents the elasticity of output with respect to labour

$\beta_{3}=A \cdot \frac{\partial Y}{\partial Z} \cdot \frac{Z}{Y}$, represents the elasticity of output with respect to the other explanatory factors

By replacing $I$ with $K$ which represents total investment.

The more general specification of the equation (3), is the most commonly used model in research of this nature and it has been utilized in various studies associated with implementing this growth model in developing economies. Several empirical studies suggest that public and private investment should be distinguished, arguing that these two types of capital stock (public and private) have exhibited different functions and productivity [9], [10], [21], [37]. Therefore, the equation (3) can be rewritten as follows;

$$
\begin{aligned}
& \frac{\Delta Y}{Y_{t-1}}= \\
& \beta_{0}+\beta_{1} \frac{P I}{Y_{t-1}}+\beta_{2} \frac{G I}{Y_{t-1}}+\beta_{3} \frac{\Delta L}{L_{t-1}}+ \\
& \quad \beta_{4} \frac{\Delta Z}{Z_{t-1}}
\end{aligned}
$$


where aggregate investment is split into private investment $(P I)$ and public investment $(G I)$. Thus, one can isolate the effect of both private and public investment on economic growth. If the impacts of private and public investment on economic growth are the same, such that $P I+G I=I$, this could imply that the respective marginal productivities of private and public investment are equal i.e. $\beta_{1}=\beta_{2}$. However, if private investment is more efficient and productive than public sector investment, then the estimated coefficient on private investment would be larger than the public investment coefficient, such that $\beta_{1}>\beta_{2}$, [9], [10], [12], [38] in particular, emphasise that the importance of the relative size of $\beta_{1}$ and $\beta_{2}$, as there remains some uncertainty about whether public sector investment encourages or depresses private investment.

Total factor productivity $(A)$ in the model is expanded to include some other determinants of economic growth in addition to capital and labour, such as real exchange rate, the inflation rate and the value of petroleum exports. Therefore the equation can be simplified for the estimation purpose as follows in a log-linear form with an error term $\mu_{t}$ :

$$
\begin{aligned}
\text { LRGDP }=\beta_{0}+ & \beta_{1} \text { LRPI }+\beta_{2} \text { LRPUB }+\beta_{3} \text { LLABOUR } \\
& +\beta_{4} \text { OIL }+\beta_{5} \text { LREXR }+\beta_{6} \text { LINFL }+\mu_{\mathrm{t}}
\end{aligned}
$$

where LRGDP represents the log of real gross domestic product, measured at 2005 prices (millions US\$); LRPI represents the log of real private gross fixed capital formation, measured at 2005 prices (millions US\$); LRPUI represents the log of real public gross fixed capital formation, measured at 2005 prices (millions US\$); LLABOUR represents the log of the size of the labour market comprising of people aged 15-64; LOILR represents the $\log$ of the real value of the petroleum exports, measured at 2005 prices (millions US\$); LREXR represents the log of the real exchange rate, calculated by multiplying the nominal exchange rate by the ratio of foreign to domestic prices using an appropriate index of prices; LINFL represents the log of the inflation rate based on the GDP deflator.

$\mu_{t}$ is the error term assumed to be normally and independently distributed with a mean of zero and a constant variance, which captures all of the other omitted explanatory variables that affect economic growth but are not included in the model. $\beta_{0}, \beta_{1}, \beta_{2}, \beta_{3}, \beta_{4}, \beta_{5}, \beta_{6}$ are the partial elasticities of the explanatory variables.

Equation (5) represents the economic growth model sued for estimation purposes in the context of Iraq from 1970 to 2010. The inflation rate, real exchange rate, and value of petroleum exports are included as independent variables in growth model, in addition to labour, public investment and private investment.

\section{A. Data Description}

Annual data on the macroeconomic variables of Iraq were collected for the period 1970-2010 and all of these variables were transformed using the natural logarithm transformation before estimation. There are no direct sources of complete data available, such that most of them are derived from various sources. The time series data for real GDP and labour size were obtained from the United Nation Conferences on Trade and Development (UNCTAD) database. The data for private GFCF and public GFCF were obtained from the handbook of annual statistics published by the the Iraqi Central Bureau of Statistics 1970-2010. Data on both the exchange rate and the inflation rate were collated from various online sources, such as the World Development Indictor of the World Bank, International Financial Statistics (IFC) and Federal Reserve Economic Data (FRED) databases. Data on the value of petroleum exports for Iraq was collected from annual statistics series compiled by the Organisation of the Petroleum Exporting Countries (OPEC). All variables are calculated in real terms by using a GDP deflator index (2005=100).

\section{B. Hypotheses}

According to theory and the empirical literature, the expected sign of all coefficients in the economic growth model to be analysed are described as follows;

$$
\beta_{1}>0, \beta_{2}>0, \beta_{3}>0, \beta_{4}>0,<0, \beta_{5}><0, \beta_{6}<0
$$

Several studies suggest that private investment, public investment, and labour size are the key determinants of economic growth and exert a positive effect on the economic growth; therefore, it is expected that all of these coefficients will exhibit a positive sign [2], [6], [10], [37], [39].

In the context of Iraq's economy, economic growth is extensively influenced by the volume of petroleum exports. The oil sector dominates Iraq's economy, as oil exports account for over $90 \%$ of government revenue, $80 \%$ of foreign exchange earnings and about $75 \%$ of GDP. Therefore, it is necessary to include this variable as a determinant of economic growth within the Iraqi economy.

Furthermore, price fluctuations and volatility in the real exchange rate are also considered to influence economic growth and These two variables are expected to have negative estimated coefficients[2], [26], [35], [40]. Since a high rate of the inflation can be a sign of macroeconomic instability and the government inability to manage the economy effectively, it is expected to have an adverse effect on the efficient allocation of the resources and thus also on economic development. The expected coefficient of real exchange rate variable is ambiguous. Economists have long known that poorly managed exchange rates can be devastating for economic growth. Avoiding large overvaluation of the currency is one of the most robust imperatives that can be strongly supported by cross-country empirical evidence [41]-[45]. The reason behind this is that overvalued exchange rates are associated with shortages of foreign currency, rent-seeking and corruption, and unsustainably large current account deficits, which are damaging to economic growth. However, devaluation of the real exchange rate may negatively impact economic growth via reducing the real income of the economy, thus causing production capacity and activity to decline [12], [34].

\section{EMPIRICAL IMPLICATION AND ANALYSIS}

\section{A. Results of Unit Root Tests}

This study begins with a standard approach to examine the stationarity of a time series in the form of unit root tests. Various tests are available, but the most common tests are the 
Augmented Dickey- Fuller (ADF) and the Phillips-Perron (PP) test. As the time series variables are in log form, it was necessary to test for stationarity and to find the order of integration of each series used in the model. If the variables are non-stationary, this can lead to 'spurious regression' and the estimated coefficients will be biased [46]; as a result, confidence intervals and hypothesis tests will be unreliable [47].

The core purpose of the Augmented Dickey- Fuller (ADF) and Phillip - Perron (PP) tests is to verify the null hypothesis of non-stationarity, the rejection of which requires a negative and significant test statistic. The optimal lag length of the lagged differences of the tested variables is determined by minimising the Akaike Information Criteria (AIC) and Schwarz Bastian criteria. All variables were examined for stationarity by utilizing the unit root test. When any time series is found to be non-stationary, then the unit root tests are to be used to determine whether the first differences of the variables are stationary.

TABLE I: THE RESUlTS OF UNIT ROOTS (AUGMENTED DiCKEy FULLER AND PHILLIPS PERRON) TESTS

\begin{tabular}{|c|c|c|c|c|}
\hline \multirow{2}{*}{ ERIES } & \multicolumn{2}{|c|}{$\begin{array}{c}\text { ADF constant with } \\
\text { trend }\end{array}$} & \multicolumn{2}{c|}{$\begin{array}{c}\text { Philips-Perron constant } \\
\text { with trend }\end{array}$} \\
\cline { 2 - 5 } & Level & $\begin{array}{c}\text { First } \\
\text { Differences }\end{array}$ & Level & Differences \\
\hline \multirow{2}{*}{ LRGDP } & -2.385 & $-6.348^{* *}$ & -2.445 & $-6.366^{* *}$ \\
\hline LRPI & -2.584 & $-5.970^{* *}$ & -2.584 & $-6.553^{* *}$ \\
\hline LRPUI & -1.581 & $-6.606^{* *}$ & -1.557 & $-6.607^{* *}$ \\
\hline LLABOUR & -0.658 & $-6.808^{* *}$ & -2.707 & $-6.808^{* *}$ \\
\hline LOIL & -2.871 & $-6.816^{* *}$ & -2.897 & $-7.065^{* *}$ \\
\hline LREXR & -1.632 & $-4.804^{* *}$ & -1.899 & $-4.778^{* *}$ \\
\hline LINF & -1.474 & $-6.159^{* *}$ & $-3.632^{*}$ & $-7.179^{* *}$ \\
\hline
\end{tabular}

Note: $*$ and $* *$ implies reject the null hypothesis of non-stationarity at $5 \%$ and $1 \%$ respectively.

Table I shows the results of the augmented dickey fuller (ADF) and Phillip perron (PP) tests applied to test each variable individually for stationarity. The underlying models include a constant and time trend. The results show that all of the model variables (LRGDP, LRPI, LRPUI, LLABOUR, $L O I L R$, and $L R E X R$ ) are stationary after computing their first differences, exception LINFL which according to the P-P test is found stationary at the level, and therefore the null hypothesis of non- stationarity is rejected for all first differenced variables. This means that variables of the time series are integrated of the order one in the first differences at a $5 \%$ and $1 \%$ significance level.

\section{B. Results of Johansen Cointgration Test}

The Johansen approach was developed by Johnasen and Juselius to examine the long run equilibrium relationship among variables [48], [49]. In the field of principle econometrics, Griffiths suggested that the temporal dynamics of the relationship between variables may play a considerable role in economic analysis; variables might drift apart in the short run, but may converge to equilibrium in the long run and the cointgration test provides an analytical instrument to assess these processes [46].
The objective of the cointegration test is to determine whether a group of non-stationary series is cointegrated or not; when all of the variables are integrated of the same order I(1), a cointegration analysis is justified. Table II displays the Johansen cointegration results based on the Trace Statistics and Maximum Eigenvalue Statistics. It can be observed that the cointegrated time series variables are exhibited a long run equilibrium relationship between them; at the $5 \%$ critical value, the Trace Statistics and Maximum Eigenvalue Statistics indicate five cointegrating vectors.

The null hypothesis of zero cointegrating vectors is rejected against the alternative of one cointegrating vector at the 5\% significance level. Similarly the null hypothesis of at most 1 , at most 2 , up to at most four cointegrating vectors is also rejected against their respective alternative hypotheses. Thus, it is concluded that there are five cointegrating vectors specified in the model.

The existence of five cointegrating vectors suggests that there are long run equilibrium relationships between gross domestic product and the explanatory variables. Accordingly, it is concluded that gross domestic product and its determinants, private investment, public investment, labour forcesize, value of petroleum exports, real exchange rate, and the inflation rate are moving together in the long run.

TABLE II: JOHANSEN COINTEGRATION TEST RESULTS

\begin{tabular}{|l|l|l|l|l|}
\hline \multicolumn{5}{|c|}{ Unrestricted Cointegration Rank Test (Trace) } \\
\hline $\begin{array}{l}\text { Null } \\
\text { Hypothesis }\end{array}$ & Eigenvalue & $\begin{array}{l}\text { Trace } \\
\text { Statistics }\end{array}$ & $\begin{array}{l}\text { 5\% } \\
\text { Critical } \\
\text { Value }\end{array}$ & Prob.** \\
\hline None * & 0.956953 & 224.5021 & 111.7805 & 0.0000 \\
\hline At most 1 & 0.928977 & 149.0112 & 83.93712 & 0.0000 \\
\hline At most 2* & 0.776097 & 85.53724 & 60.06141 & 0.0001 \\
\hline At most 3* & 0.649133 & 49.62022 & 40.17493 & 0.0043 \\
\hline At most 4* & 0.599325 & 24.48386 & 24.27596 & 0.0471 \\
\hline At most 5 & 0.092224 & 2.533366 & 12.3209 & 0.9017 \\
\hline At most 6 & 0.008761 & 0.211185 & 4.129906 & 0.7024 \\
\hline Unrestricted Cointegration Rank Test (Maximum Eigenvalue) \\
\hline Null \\
Hypothesis & Eigenvalue & $\begin{array}{l}\text { Eigenvalue } \\
\text { Statistics }\end{array}$ & $\begin{array}{l}\text { Critical } \\
\text { Value }\end{array}$ & Prob.** \\
\hline None * & 0.956953 & 75.49089 & 42.77219 & 0.0000 \\
\hline At most 1 * & 0.928977 & 63.47393 & 36.63019 & 0.0000 \\
\hline At most 2* & 0.776097 & 35.91702 & 30.43961 & 0.0094 \\
\hline At most 3* & 0.649133 & 25.13635 & 24.15921 & 0.0368 \\
\hline At most 4* & 0.599325 & 21.9505 & 17.7973 & 0.0112 \\
\hline At most 5 & 0.092224 & 2.322181 & 11.2248 & 0.8847 \\
\hline At most 6 & 0.008761 & 0.211185 & 4.129906 & 0.7024 \\
\hline
\end{tabular}

Note: Trace statistics test and Max-eigenvalue statistics indicate 5 cointegrating equations at 0.05 level, $*$ denotes rejection of the hypothesis at the 0.05 level, **MacKinnon-Haug-Michelis (1999) p-values.

The $\beta$ coefficients expressed in terms of the normalised cointegrating coefficients of first equation is given in Table III, showing the long run relationship amongst the variables. In general, the signs of the estimated coefficients for all variables are strongly consistent with the macroeconomic theory, as well as being statistically significant. Since all of the variables are estimated with a natural log transformation, the estimated coefficients of each variable can be described as a long run elasticity. 
TABLE III: NORMALIZED COINTEGRATING COEFFICIENTS

\begin{tabular}{|c|c|c|c|}
\hline Variables & Coefficients & $\begin{array}{c}\text { Standard } \\
\text { Errors }\end{array}$ & T-statistics \\
\hline LRPI & 0.0488 & 0.019 & -2.5684 \\
\hline LRPUI & 0.3997 & 0.023 & -17.3783 \\
\hline LLABOUR & 0.0052 & 0.0014 & -3.7143 \\
\hline LOIL & 0.2830 & 0.0189 & -14.9735 \\
\hline LREXR & -0.0249 & 0.0076 & 3.2763 \\
\hline LINF & -0.0295 & 0.0058 & 5.0863 \\
\hline
\end{tabular}

The cointgration equation can be written as follows:

\section{$L R G D P=0.048 L R P I+0.399 L R P U I+0.005 L L A B O U R+$ $0.283 L O I L-0.025 L R E X R-0.029 L I N F L$}

To determine whether real public investment is more productive than real private investment, the two coefficients can be compared according to the approach adopted by Khan and Reinhart [10]. Although both of the estimated coefficients on the private and public investment variables have a positive and significant effect on gross domestic product in the long run, the coefficient of the real public investment variable is greater than the coefficient on the real private investment variable. Therefore, it can be concluded that, in the long run, real public investment was more productive than real private investment in encouraging GDP growth over the time period analysed.

The RPI elasticity of GDP is (0.048) which less than RPUI elasticity of $R G D P(0.399)$,suggesting that a one unit increase in RPUI will bring about a $0.339 \%$ increase in $R G D P$, while a one unit increase in RPI will bring about $0.048 \%$ increase in $R G D P$. This result was expected since the economic policy that has been adopted in the last forty years by the Iraqi government has supported public investment more than private investment. This outcome may not mean that real public investment is more efficient or productive than private investment in the context of Iraq, but might suggest that the presence of the 'crowding-out' effect that depresses private investment; neither played its real role in the economy nor contributed this much in the RGDP. However, in both cases a percentage increase in any of these variables leads to an increase in real GDP, supporting theoretical propositions and previous empirical findings that both public and private investment have a positive impact on economic growth [9], [12], [21].

The endogenous growth models developed by Lucas and Robert [17] that challenged the neoclassical model by emphasizing the role of human capital in economic growth. Furthermore, it has suggested by a number of empirical studies [6], [10], [39], [10], [50] that the size of the labour force is another important variable that positively influences economic growth. As indicated in the Table III, the parameter estimate for the labour force variable, although positive, has only a slight impact on economic growth, such that a $1 \%$ point increase in the size of the labour force will cause a $0.0052 \%$ point increase in economic growth, ceteris paribus.

Although the oil sector continues to provide the basic means for growth and stability in the medium term in Iraq, accounting for over $90 \%$ of government revenue and a $75 \%$ share of GDP, economic diversification is important in the long run. The estimated coefficient on the petroleum variable is both positive and significant (0.2830), indicating that $1 \%$ point increase in the real interest rate would decrease GDP by $0.2830 \%$ point. This result is consistent with the reality of Iraq's economy, as increasing oil revenue accelerates economic growth through the provision of basic infrastructure and improvements in a legal framework.

Finally, inflation is seen to influenc real GDP negatively and significantly, as a $1 \%$ rise in the inflation rate would result in a $0.025 \%$ reduction in GDP. This outcome, consistent with theory and the empirical literature [37], [51] and suggests that high inflation rates adversely affect economic development. The results also show that the real exchange rate also has negative and significant effect on real GDP. The estimates suggest that a $1 \%$ increase in the real exchange rate would cause a $0.0295 \%$ reduction in real GDP. What can be concluded here is that, as these two variables are associated directly with investment, volatility in prices and the real exchange rate produces greater uncertainty in the economy that depresses economic development as a result.

\section{Short Run Dynamics of Economic Growth in Iraq}

A feature of cointegration is that short and long run effects can be isolated, as short run effects may differ from their long-run equilibrium. In order to understand the nature of GDP growth, this study examines the short run dynamics between real GDP and its determinants. This lead to the specification of a general ECM specified in the following form;

$$
\begin{aligned}
& \Delta L R G D P_{t}= \\
& \beta_{1}+\sum_{i=0}^{n} \beta_{2 i} \Delta L R P I_{t-i}+\sum_{i=0}^{n} \beta_{3 i} \Delta L R P U I_{t-i_{i, t}}+ \\
& \sum_{i=0}^{n} \beta_{4 i} \Delta L A B O U R_{t-i_{i, t}}+\sum_{i=0}^{n} \beta_{5 i} \Delta L \text { OILR }_{t-i_{i, t}}+ \\
& \sum_{i=0}^{n} \beta_{6 i} \Delta L R E X R_{i-t}+\sum_{i=0}^{n} \beta_{7 i} \Delta L I N F_{t-i}+ \\
& \beta_{8 i} E_{C M}+M_{t-1}+\mu_{t}
\end{aligned}
$$

where $\mathrm{ECM}_{t-1}$ is the one period lagged error correction term that includes the residuals obtained from the estimated cointegration model of equation (6). The ECM is the adjustment effect showing how much of the disequilibrium is being corrected. It also tests the stability of the long run relationship that is highly statistically significant [52]. The symbol $\Delta$ refers to the first- differenced form of the variables in the model. The coefficients $\beta_{1 i}, \beta_{2 i} \ldots \beta_{7 i}$ of the explanatory variables in equation (6) refer to the impact of multipliers that measure the immediate influence that a change in the explanatory variables have on a change in the dependent variable, whilst the coefficient $\beta_{8 i}$ reflects the speed of the adjustment parameter. The common belief with the error correction model is that the value of $\beta_{8 i}$ should be lie in the range $-1 \leq \beta_{8 i} \geq 0$ and should be statistically significant in order to confirm the long run relationship among variables.

The results of the short run vector error correction model (VECM) are shown in the Table IV. This VECM associates the changes in real GDP to changes in the other lagged variables and the disturbance term of the lagged period. The coefficient of the speed of adjustment is negative and significant and he magnitude of this coefficient, -0.5459 , suggests that after the economic system experiences a shock, it takes approximately five periods in order to restore its equilibrium 
According to Table IV, in the short run the estimated coefficients of the all the explanatory variables have the same sign as in the long run. In the short run, Private investment, public investment, growth in the labour force, and growth in the value of petroleum exports are still seen to have positive impacts, while real exchange rate and inflation rate volatility still have negative impacts on economic growth.

However, the most significant variables that are seen to influence economic growth are public investment and the real exchange rate and the immediate effects of the public investment and real exchange rate variables have a positive and negative impact on real GDP, respectively. In the short run, the estimates suggest that a $1 \%$ increase in the previous year public investment will cause real GDP to grow by $0.14 \%$, whilst an increase in the real exchange rate causes real GDP to decrease by about $0.09 \%$. However, the other explanatory variables are not seen to have a significant impact on economic growth in the short run.

TABLE IV: THE RESULTS OF SHORT-TERM VECTOR ERROR CORRECTION MODEL (VECM)

\begin{tabular}{|c|c|c|c|}
\hline Variables & Coefficient & Standard error & T-statistics \\
\hline$D(L R P I(-1))$ & 0.0839 & 0.0764 & 1.0981 \\
\hline$D($ LRPUI $(-1))$ & 0.1419 & 0.0668 & 2.1251 \\
\hline$D(\operatorname{LOILR}(-1))$ & 0.1248 & 0.0887 & 1.4075 \\
\hline$D(L L A B O U R(-1))$ & 0.0469 & 0.1988 & 0.2359 \\
\hline$D(\operatorname{LREXR}(-1))$ & -0.0925 & 0.0135 & -6.8483 \\
\hline$D(\operatorname{LINFL}(-1))$ & -0.043 & 0.0312 & -1.3771 \\
\hline $\operatorname{ECM}(-1)$ & -0.5459 & 0.1624 & -3.3611 \\
\hline R-squared & 0.9289 & Mean dependent var & 10.0506 \\
\hline $\begin{array}{c}\text { Adjusted } \\
\text { R-squared }\end{array}$ & 0.9137 & S.D. dependent var & 0.4567 \\
\hline S.E. of regression & 0.1341 & Akaike info criterion & -1.0031 \\
\hline Sum squared resid & 0.5038 & Schwarz criterion & -0.6920 \\
\hline Log likelihood & 24.5545 & Hannan-Quinn criter. & -0.8957 \\
\hline F-statistic & 61.0139 & \multirow[t]{2}{*}{ Durbin-Watson stat } & \multirow[t]{2}{*}{1.6236} \\
\hline Prob(F-statistic) & 0.0000 & & \\
\hline
\end{tabular}

As can be observed in the Table IV, the results show that the overall performance of the estimated equation is satisfactory. The value of the adjusted $R^{2}(0.84)$, which is used to measure the explanatory power of the model, appears to be reasonably high based on the Iraq data used here. Moreover, F-statistic $(61.0139 \%)$, measuring the joint significance of all the regressed explanatory variables in the model, is significant at $1 \%$ level of significance, suggesting that the model explains a highly significant amount of variation. Furthermore, the Durbin-Watson test shows that there is no autocorrelation in the residuals of the model. Additionally, in order to test whether the model is correctly specified, several diagnostic tests were conducted on the residuals from the model; the results of these diagnostic tests residuals are normally distributed, with no serial autocorrelation or heteroskedasticity being present. Thus, we can conclude that the model is correctly specified.

\section{CONCLUSION AND RECOMMENDATIONS}

This study examined the macroeconomic determinants of long run economic growth in Iraq based on a neoclassical growth framework. The empirical analysis employed a cointegration approach using time series data from 1970 to 2010. The results of the Johansen's cointegration test indicate that there are several significant relationships between GDP growth and the explanatory variables examined her. In the long run, the empirical results suggest that both forms of investment (public and private), growth in labour force, and growth in oil revenue have a positive and significant impact on economic growth, whilst the real exchange rate and macroeconomic instability negatively and significantly affect GDP. However, in the short run, public investment and the real exchange rate are found the have significantly positive and negative effects on real GDP respectively. This study also assessed the distinction between the impacts of public and private investment on economic growth, and found the public investment contributed to economic growth to a greater extent than private investment in Iraq between 1970 and 2010.

According to the empirical results, the following policy recommendations are made; Economic policies should be put in place to increase both public and private forms of physical capital. Specifically, the Iraqi government needs to increase spending on the more productive sectors in the economy, such as the health and agriculture sectors, whilst also increasing spending on infrastructure services. Consequently, this will increase productivity in these sectors and encouraging increases in private investment. Since oil revenue is already the main source for government revenue and is also observed to have a positive impact on the economic growth, the Iraqi government should look to adopt extensive policies to strengthen non-oil sectors in order to diversify, and ultimately strengthen, the Iraqi economy. Furthermore, there is a need to allocate some of this oil revenue to improve human capital through incentivise educational institutions to produce the graduates demanded by a number of industries, such as domestic manufacturing, non -oil export trade, banking, and financial institutions. Finally, the results of the empirical models suggest that macroeconomic instability and currency devaluation may be a substantial threat to economic growth, as it discourages new potential investment, reduces profitability and reduces the international competitiveness of existing investment.

\section{ACKNOWLEDGEMENTS}

J. H. Author thanks the financial support of the Ministry of Higher Education and Scientific Research, Kurdistan Regional Government (KRG), KRG-Scholarship program Human Capacity Development.

\section{REFERENCES}

[1] D. A. Aschauer, "Does public capital crowd out private capital?" Journal of Monetary Economics, vol. 24, no. 2, pp. 171-188, 1989.

[2] L. Erden and R. G. Holcombe, "The Linkage between public and private investment: A co-integration analysis of a panel of developing countries," Eastern Economic Journal, vol. 32, no. 3, pp. 479-492, 2006.

[3] S. J. Erenburg. "The real effects of public investment on private investment," Applied Economics, vol. 25, no. 6, pp. 831-837, 1993.

[4] A. M. Pereira, "On the effects of public investment on private investment: what crowds in what?" Public Finance Review, vol. 29, no. 1, pp. 3-25, 2001.

[5] H. Seitz and K. Conrad, "The economic benefits of public infrastructure," Applied Economics, vol. 26, no. 4, pp. 303-311, 1994.

[6] M. I. Blejer and M. S. Khan, Government Policy and Private Investment in Developing Countries Staff Papers-International Monetary Fund, pp. 379-403, 1984. 
[7] E. Cavallo and C. Daude. "Public investment in developing countries: A blessing or a curse?" Journal of Comparative Economi, vol. 39, no. 1, pp. $65-81,2011$.

[8] A. Afonso and M. S. T. Aubyn, "Macroeconomic rates of return of public and private investment: crowding-in and crowding-out effects," The Manchester School, vol. 77, pp. 21-39, 2009.

[9] Y. Zou, "Empirical studies on the relationship between public and private investment and GDP growth," Applied Economics, vol. 38, no. 11 , pp. 1259-1270, 2006.

[10] M. S. Khan and C. M. Reinhart, "Private investment and economic growth in developing countries," World Development, vol. 18, no. 1, pp. 19-27, 1990.

[11] N. Nazmi and M. D. Ramirez, "Public and private investment and economic growth in Mexico," Contemporary Economic Policy, vol. 15 no. 1 , pp. 65-75, 1997.

[12] F. Kandenge, Public and Private Investment and Economic Growth in Namibia, Available at SSRN 1310595, 2007.

[13] C. Foote et al., "Economic policy and prospects in Iraq," The Journal of Economic Perspectives, vol. 18, no. 3, pp. 47-70, 2004.

[14] N. G. Mankiw, D. Romer, and D. N. Weil, "A contribution to the empirics of economic growth," The Quarterly Journal of Economics, vol. 107 , no. 2, pp. 407-437, 1992.

[15] R. J. Barro, "Human capital and growth," American Economic Review, pp. 12-17, 2001

[16] M. S. Oosterbaan, T. D. R. V.Steveninck, and N. V. D. Windt, "The determinants of economic growth," London: Kluwer Academic Publishers, 2002.

[17] J. Lucas and E. Robert, "On the mechanics of economic development," Journal of Monetary Economics, vol. 22, no. 1, pp. 3-42, 1988.

[18] B. Fleisher, H. Li, and M. Q. Zhao, "Human capital, economic growth, and regional inequality in China," Journal of Development Economics, vol. 92, no. 2, pp. 215-231, 2010.

[19] A. Chhibber, M. Dailami, and N. Shafik, "Reviving private investment in developing countries: empirical studies and policy lessons," North-Holland, 1992.

[20] V. Sundararajan and S. Thakur, "Public investment, crowding out, and growth: a dynamic model applied to India and Korea," IMF Staff Papers, vol. 27, no. 4, pp. 814-855, 1980.

[21] M. Khan and M. S. Kumar, "Public and private investment and the growth process in developing countries," Oxford Bulletin of Economic and Statistics, vol. 59, no. 1, pp. 69-88, 1997.

[22] J. Greene and D. Villanueva, "Private investment in developing countries: an empirical analysis," Staff Papers-International Monetary Fund, pp. 33-58, 1991.

[23] T. W. Oshikoya, "Macroeconomic determinants of domestic private investment in Africa," An Empirical Analysis Economic Development and Cultural Change, vol. 42, no. 3, pp. 573-590, 1994.

[24] P. J. Montiel, Macroeconomics in Emerging Markets, Cambridge University Press, 2011.

[25] N. P. Ifeakachukwu, A. O. Omodadepo, and A. A. Oluseun, An Analysis of the Relationship between Public Spending Components and Private Investments in Nigeria Journal of Finance and Economics, vol, 1 , no. 2, pp. 14-27, 2013.

[26] D. Ghura and B. Goodwin, "Determinants of private investment: a cross-regional empirical investigation," Applied Economics, vol. 32, no. 14 , pp. 1819-1829, 2000.

[27] M. Brownbridge, "Pivate investment and public structural change in developing countries," unpublished Ph.D. thesis, IDPM, Unvirsity of Manchester, England, 1994.

[28] A. Badawi, "Private capital formation and public investment in Sudan: testing the substitutability and complementarity hypotheses in a growth framework," Journal of International Development, vol. 15, no. 6, pp. 783-799, 2003.

[29] N. Shafik, "Modelling private investment in Egypt," Journal of Development Economics, vol. 39, no. 2, pp. 263-277, 1992.

[30] N. H. Naqvi, "Crowding-in or Crowding-out? Modelling the relationship between public and private fixed capital formation using co-integration analysis: the case of Pakistan 1964-2000," The Pakistan Development Review, pp. 255-275, 2002.

[31] P. Keefer and S. Knack, "Boondoggles, rent-seeking, and political checks and balances: public investment under unaccountable governments," The Review of Economics and Statistics, vol. 89, no. 3, pp. 566-572, 2007.

[32] P. Mauro, "The effects of corruption on growth, investment, and government expenditure," International Monetary Fund, 1996.

[33] S. Khan and M. A. Khan, "What determines private investment?: the case of pakistan," Pakistan Institute of Development Economics, 2007.

[34] M. T. Majeed and S. Khan, "The determinants of private investment and the relationship between public and private investment in pakistan," NUST Journal of Business and Economics, vol. 1, no.1, 2008.
[35] M. Rama, "Empirical investment equations for developing countries," Striving for Growth after Adjustment: the Role of Capital Formation, pp. 107-143, 1993

[36] M. Baghebo and S. Edoumiekumo, "Domestic private capital accumulation and economic development in nigeria 1970-2010," International Journal, vol. 2, 2012.

[37] D. Ghura, "Private investment and endogenous growth: evidence from Cameroon," International Monetary Fund, 1997.

[38] S. K. Mallick, "Determinants of long-term growth in India: a Keynesian approach," Progress in Development Studies, vol. 2, no. 4, pp. 306-324, 2002.

[39] M. D. Ramirez and N. Nazmi, "Public investment and economic growth in Latin America: An empirical test," Review of Development Economics, vol.7, no. 1, pp. 115-126, 2003.

[40] O. Razin and S. M. Collins, "Real exchange rate misalignments and growth," National Bureau of Economic Research, 1997.

[41] S. Johnson, J. Ostry, and A. Subramanian, "The prospects for sustained growth in Africa: Benchmarking the constraints," National Bureau of Economic Research Cambridge, Mass, USA, 2007.

[42] R. G. Rajan and A. Subramanian, "Aid, Dutch disease, and manufacturing growth," Journal of development Economics, vol. 94, no. 1 , pp. 106-118, 2011

[43] W. Easterly, "National policies and economic growth: a reappraisal," Handbook of Economic Growth, vol. 1, pp. 1015-1059, 2005.

[44] D. Rodrik, "The real exchange rate and economic growth," Brookings Papers on Economic Activity2008, vol. 2, pp. 365-412, 2008.

[45] M. K. Isaac and K. C. Samwel, "Effects of fiscal policy on private investment and economic growth in Kenya," Journal of Economics and Sustainable Development, vol. 3, no. 7, pp. 8-16, 2012.

[46] W. E. Griffiths, R. C. Hill, and G. C. Lim, Using EVIEWS: For Principles of Econometrics, 2008.

[47] C. W. Granger, "Some properties of time series data and their use in econometric model specification," Journal of Econometrics, vol. 16, no. 1 , pp. 121-130, 1981

[48] S. Johansen, "Determination of cointegration rank in the presence of a linear trend," Oxford Bulletin of Economics and Statistics, vol. 54, no. 3, pp. 383-397, 1992.

[49] S. Johansen and K. Juselius, "Maximum likelihood estimation and inference on cointegration - with applications to the demand for money," Oxford Bulletin of Economics and Statistics, vol. 52, no. 2, pp 169-210, 1990.

[50] K. A. Anaman, "Determinants of economic growth in Brunei Darussalam," Journal of Asian Economics, vol. 15, no. 4, pp. 777-796, 2004.

[51] E. D. K. Havi et al., "Macroeconomic determinants of economic growth in Ghana: cointegration approach," European Scientific Journal, vol. 9, no. 19, 2013.

[52] N. R. Ericsson and E. L. Reisman, "Evaluating a global vector autoregression for forecasting," International Advances in Economic Research, vol. 18 , no. 3, pp. 247-258, 2012

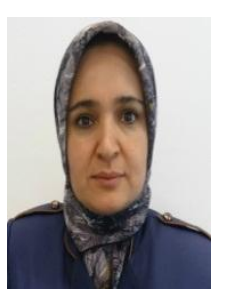

Jwan Saeed Hussein was born in Kurdistan Erbil, Iraq, on July 1, 1977. She was awarded a B.Sc. degree in economics with a very good grade from the College of Administration and Economics, Salahaddin University, Erbil Iraq on June 21, 1999. She was then awarded a M.Sc. degree in economics on August 3, 2004, also from the College of Administration and Economics, Salahaddin University, Erbil, Iraq. The author is currently a full-time student at Plymouth University, having successfully transferred from the $\mathrm{MPhil} / \mathrm{PhD}$ to $\mathrm{PhD}$ programme, studying towards a $\mathrm{PhD}$ in Business with management.

She has worked in the College of Administration and Economics at Salahaddin University first as a research assistant from 1999-2002, and later as a lecturer until 2011. She has a diligent work ethic and committed to completing all aspects of a working project thoroughly, promptly and efficiently. She was self-motivated and has always been very keen to consistently improve her knowledge base and enhance her skills. During her work, she was responsible for delivering high quality learning within the area of Economics. She produced learning, teaching and assessment materials, and delivered excellent teaching within the specialist area of Economics. She delivered lectures to groups of students and organized, implemented and monitored programmes and assessments

She is currently a full-time student at Plymouth University, conducting research towards a $\mathrm{PhD}$ in the Graduate School of Management, Cookworthy Building, Drake Circus, Plymouth, Devon, United Kingdom, PL4 8AA. Her present research interests concern economic development, econometrics modeling, and time series analysis 